\title{
VICTORIAN SEXUAL POLITICS AND THE UNSETTLING CASE OF GEORGE ELIOT'S RESPONSE TO WALT WHITMAN
}

\author{
Beverley Park Rilett
}

George Eliot and Walt Whitman, two of the most influential writers of the nineteenth century, are rarely discussed in relation to one another. They did not correspond, nor did either writer ever cross the Atlantic. There may have been several degrees of separation between Eliot and Whitman personally, but even from a distance, the two writers influenced each other's careers. There has been some misconception that Eliot disdained and discounted Whitman. This essay seeks to refute that assumption by examining the context in which Eliot appeared to reject him. Perhaps more significantly, this essay breaks new critical ground by attributing a second review of Whitman's 1855 Leaves of Grass to George Eliot.

This study examines statements Eliot and Whitman made about one another, and considers the interrelationships of the people they knew in order to demonstrate that Eliot and her domestic partner George Henry Lewes played significant roles in Whitman's British reception. This new information about their mutual friendships and avenues of promotion supplements several foundational studies of Whitman's British or European reception undertaken by Clara Barrus, Harold Blodgett, Eve Kosofsky Sedgwick, M. Wynn Thomas, Joann P. Krieg, Betsy Erkkila, and Michael Robertson. ${ }^{1}$ These scholars have traced Whitman's network of supporters across the Atlantic without noticing that Eliot and Lewes were members of the relatively small circle of influential British intellectuals that embraced and promoted Whitman in Britain early in his career. Finally, this essay posits several reasons why, after initially endorsing Whitman in 1856, Eliot appeared to withdraw her support in 1876 . We see in her changing response to Whitman an example of how Eliot responded to the pressures of nineteenth-century sexual politics and her own celebrity status by self-censoring and coding sexuality, particularly same-sex desire, in her fiction, which extends scholarship by Nancy Henry, Kathleen McCormack, Laura Callanan, and Dennis S. Gouws, among others. ${ }^{2}$ 
The Victorian writer who called herself George Eliot and her partner George Henry Lewes occupied positions of prominence in Britain's literary world at the time Whitman was publishing his various editions of Leaves of Grass in the United States. Eliot and Lewes interacted regularly with many of the Victorian era's best-known authors, critics, and publishers. ${ }^{3}$ Before she became a famous novelist with the pen name George Eliot - the name on her tombstone, on all her biographies, and by which she still is known-she was Marian Evans, the enterprising journalist. By 1851, she was living independently in London, writing articles and reviews for several periodicals and serving as the managing editor of one of Britain's leading journals, the Westminster Review. ${ }^{4} \mathrm{Her}$ work brought her into contact with prominent intellectuals including George Henry Lewes, a frequent contributor to the Review. Lewes was well established in literary London as one of the most versatile of writers and editors. He wrote novels, biographies, philosophy, theater and book reviews, scientific articles, and he abridged plays. In 1850, Lewes co-founded with Thornton Hunt the Leader weekly newspaper; in 1860, Lewes became consulting editor of the Cornhill, while Hunt assumed leadership of the Spectator. By 1865, Lewes had become the inaugural editor of the Fortnightly Review. He also acted as adviser for George Smith's Pall Mall Gazette from 1865-68 while he was editing the Fortnightly Review (Baker and Ross 421). These literary associations demonstrate that Lewes and Eliot, who were a couple by 1852 and living together by 1854 , were closely connected with the writers and editors of the Victorian British periodicals that favorably reviewed Walt Whitman's poetry for more than twenty years, specifically the Westminster Review, the Spectator, the Cornhill, the Pall Mall Gazette, the Leader, and the Fortnightly Review.

The copies of Whitman's original Leaves of Grass that were circulated in London in the early spring of 1856-remaindered copies of the original 1855 edition - had pasted into them several American notices of the book. ${ }^{5}$ The ad hoc front matter, which later was supplemented and incorporated as "Leaves-Droppings" in the 1856 edition of Leaves, succeeded in getting Whitman's work noticed. The first review of Leaves in Britain, published in the Saturday Review on March 15, 1856, included the following:

We have received a volume, bound in green, and bearing the above title, under rather singular circumstances. Not only does the donor send us the book, but he favours us with hints - pretty broad hints - towards a favourable review of it. He has pasted in the first page a number of notices extracted with the scissors from American newspapers, and all magnificently eulogistic of Leaves of Grass. So original a proceeding merits an exceptional course; and therefore we shall confine ourselves to laying before our readers, first, the opinions of the American reviewers, and next giving specimens of 
Though Whitman was easily identified and outed as the writer of his own glowing reviews, ${ }^{7}$ his attempt to demonstrate that America was abuzz over a new poet did attract the British literati. One could argue that the ends justified the means, because even though his deception was discovered, negative publicity often generates ample attention and almost as many sales as positive publicity. Though the Saturday Review notice did not mention Whitman's self-promotion, it did end, surprisingly, with a refusal to endorse the book. The anonymous reviewer concluded that Whitman's poetry was so frequently "obscene ... [that] [i]f the Leaves of Grass should come into anybody's possession, our advice is to throw them instantly behind the fire." Some readers might have avoided the book based on this advice, but others might have had their curiosity piqued and might well have wanted to judge for themselves what was obscene about this new poetry. As regular reviewers of new literature, Lewes and Eliot probably received a similar volume to the one sent to the Saturday Review, but Eliot arrived at a more favorable assessment of Whitman's work.

George Eliot was the first reviewer to write a positive notice of Leaves of Grass published in Britain. Two weeks after the Saturday Review berated the book, Eliot's appraisal appeared in the April 1, 1856, Westminster Review at the end of a long, anonymously published "Belles Lettres" column in which Eliot also reviewed Ruskin's Modern Painters and several other contemporary works. ${ }^{8}$ Noting that "some Transatlantic critics" believed Leaves would initiate a new school of poetry-a comment that seems to allude to the inserted American reviews-Eliot quoted two eleven-line segments from the poem Whitman eventually titled "Song of Myself." She quoted lines 90-100, which begin with, "A child said, What is the grass?" and another segment, lines 684-94, which begins with, "I think I could turn and live awhile with the animals." Evidently, Eliot was drawn to Whitman's scenes of natural beauty-the inherent magnificence of animals, blades of common grass, and an innocent child. Moreover, she contends that these selections are "typical in every respect," which implies that similar scenes of beauty she found throughout Whitman's Leaves would be equally worthy of notice. But Eliot adds a caveat - these excerpts are typical only to a point. There is another aspect of Whitman's work that is also representative-some "very bold expressions," which Eliot intentionally withholds from her readers in order to respect "the 'prejudices' of decency" that Whitman contemptuously violates throughout his poetry. Eliot's use of the word "prejudices" and her decision to place this word within quotation marks suggests that she recognizes and defers to the reading public's norms of decency even as she calls them into question as "prejudices." Her 
own definition of decency, she implies, is less prejudiced, more lenient, though inexpressible within the pages of the Westminster Review.

Instead of revolution, Eliot always advocated for gradual social progress; her cautious endorsement of Whitman in this review is entirely consistent with her general philosophy. ${ }^{9}$ It is significant that the week after Eliot reviewed Whitman, she began an essay on the nature of tragedy in Sophocles' Antigone, a new edition of which had recently been published by Oxford Pocket Classics for the use of schools. ${ }^{10}$ The two essays were published mere days apart- "The Antigone and Its Moral" appeared in the Leader on March 29, and Eliot's review of Leaves was part of her "Belles Lettres" column in the Westminster Review on April 1, 1856. ${ }^{11}$ There are significant parallels between the two. That Eliot was thinking beyond Antigone is evident in her comment, "Wherever the strength of a man's intellect, or moral sense, or affection bring him into opposition with the rules which society has sanctioned, there is renewed the conflict between Antigone and Creon."12 While she sympathizes with Antigone's "elemental tendencies," Eliot also insists that Creon must be viewed as a "legitimate ruler":

It is a very superficial criticism which interprets the character of Creon as that of a hypocritical tyrant, and regards Antigone as a blameless victim....The exquisite art of Sophocles is shown in the touches by which he makes us feel that Creon, as well as Antigone, is contending for what he believes to be the right, while both are also conscious that, in following out one principle, they are laying themselves open to just blame for transgressing another.

Creon's “established laws" may not be perfect, but they are the necessary means

by which the outer life of man is gradually and painfully being brought into harmony with his inward needs. Until this harmony is perfected, we shall never be able to attain a great right without also doing a wrong. Reformers, martyrs, revolutionists, are never fighting against evil only; they are also placing themselves in opposition to a good-to a valid principle which cannot be infringed without harm. . . Perhaps the best moral we can draw is that to which the Chorus points - that our protest for the right should be seasoned with moderation and reverence. (Pinney 264-265)

As we turn to consider what in all likelihood was Eliot's second review of Leaves of Grass, it will become evident that these passages from her essay on Antigone are relevant to an assessment of her writing about Whitman, who, like Antigone, had good reasons for challenging society's restrictive regulations. Eliot felt compelled to explain in each case that the good of revolution must be balanced against the good of social stability. In each successive article-the first review of Leaves, the Antigone review, and then the second review of Leaves-Eliot appears to have 
reflected on and expanded her position on the ideal balance between individual freedom and responsibility to one's community.

Only a few weeks after Eliot's Westminster Reviezw notice of Leaves of Grass appeared, another unsigned review of Whitman's work, "Transatlantic Latter-Day Poetry," was published in the Leader on June 7, 1856. ${ }^{13}$ Its conditional admiration of Whitman's poetry bears a number of resemblances to the Westminster Review notice. It opens with the acceptance (perhaps on the evidence of the inserted newspaper clippings) that Whitman had become "a certain phenomenon" who "has been received by a section of his countrymen as a sort of prophet," whereas the English generally viewed him "as a kind of fool." According to the Leader's reviewer, however, Whitman was neither a latter-day prophet nor a fool; instead, he had elements of both. His book is described as "strange, grotesque, and bewildering" but also "one of the most amazing, one of the most startling, one of the most perplexing, creations of the modern American mind." To demonstrate "the vividness with which Walt can paint the unhackneyed scenery of his native land," the reviewer presents "a panorama" of twenty-four lines - the same theme and nearly the same number of lines that Eliot had selected for her Westminster Review notice.

Most significantly, the heart of the Leader review carries the same message as the Westminster Review's: the writer, while delighting in Whitman's "noble soul," contends that the poet has gone too far, which, unfortunately, has the "effect of discrediting what is genuine by the show of something false." The "key to this book," according to this reviewer, is the " $[t]$ he singularity of the author's mind" in which he "sympathizes deeply with humanity; riots with a kind of Bacchanal fury in the force and fervour of his own sensations; will not have the most vicious or abandoned shut out from final comfort and reconciliation ... and beholds all beings tending towards the central and sovereign Me." These insights are complimentary, but again we find a caveat. The Leader reviewer deplores Whitman's intention to "remove the veil" from the subject of human sexuality, as stated in his opening poem (which became "Song of Myself"):

Through me forbidden voices,

Voices of sexes and lusts . . . voices veiled, and I remove the veil, Voices indecent by me clarified and transfigured.

I do not press my finger across my mouth,

I keep as delicate around the bowels as around the head and heart,

Copulation is no more rank to me than death is.

I believe in the flesh and the appetites . . . ${ }^{14}$ 
The review ends with a limited endorsement of Whitman's Leaves: "[E] specially do we deplore the unnecessary openness with which Walt reveals to us matters which ought rather to remain in a sacred silence. It is good not to be ashamed of Nature; it is good to have an all-inclusive charity; but it is also good, sometimes, to leave the veil across the Temple." Where Whitman insisted on removing the veil, Eliot preferred to leave it in place. This assessment echoes Eliot's cautionary Westminster Review notice, which censured Whitman's "very bold expressions" for showing "contempt for the 'prejudices' of decency" even as she endorsed the rest of his poetry. It also presents a strikingly similar message, as we have seen, to Eliot's essay that qualified Antigone's heroism by emphasizing her social recklessness. Throughout Eliot's writing, a desire for social progress is tempered by a belief that change must be gradual rather than revolutionary if it is to last. The overall message of the Leader review, especially its concern about Whitman's "unnecessary openness," is remarkably consistent with the messages of Eliot's earlier articles.

In 1856, the Westminster Review and the London Leader weekly newspaper were among the leading literary periodicals. These positive though tempered reviews helped popularize Whitman's first edition of Leaves of Grass with a select group of intellectuals, if not with the British reading public at large. Given the importance of these early reviews, it is somewhat surprising that scholars have not previously connected George Eliot and George Henry Lewes to Whitman's British supporters. One should bear in mind, however, that literary reviews were published anonymously in most Victorian periodicals and tracking down the authors of anonymous reviews can be challenging or futile. Though the publications themselves have survived, there are many instances in which the records of contributors have not; in such cases a determination of authorship must rely on circumstantial evidence.

The unsigned Leader review, "Transatlantic Latter-Day Poetry," was attributed to George Henry Lewes in $2007 .{ }^{15}$ No source is listed for this attribution to Lewes, but it was probably Edward Dowden's addendum to Richard Maurice Bucke's biography, "English Critics on Walt Whitman."16 Dowden quotes from a letter William Michael Rossetti wrote him in 1884 - twenty-eight years after the review was published and after both Lewes and Eliot had died-in which Rossetti attributed to Lewes the first British review of Leaves of Grass. Rossetti was not sure that Lewes had written the 1856 review but reasoned that, because Lewes was then editor of the Leader, it was "generally accepted as being his." This was a reasonable assumption because Lewes did write the Leader's "Literature" column at the time, but Rossetti's partially-informed assumption hardly qualifies as definitive proof that 
Lewes was the author. The preponderance of evidence suggests that George Eliot wrote it.

First, biographical evidence supports the likelihood that George Eliot wrote a second, longer review of Whitman's Leaves. Lewes was unwell for several weeks prior to the review's June 1856 publication. From May to August 1856, the couple visited the Welsh coast so that Lewes could rest from his writing and take some fresh air away from London, in addition to pursuing his new interest in marine biology. When Lewes was ill, his physicians would instruct him to take "rest cures" or spa vacations; Eliot sometimes wrote Lewes's columns for him during these periods of rest. ${ }^{17}$ It is evident from a letter penned on June 6 that Eliot was very concerned about Lewes's health at this time: "The partial rest from writing he has had, and the change of air, have already done him good, and I am hoping that with two more months of this life he may even get rid of that terrible singing in his ears which has never left him since the commencement of his illness two years ago."18 Eliot's biographers and bibliographers concur that it was not unusual for Eliot to write articles to help fill out Lewes's periodicals. ${ }^{19}$ She was a brilliantly capable and helpful mate who read to Lewes regularly, translated research materials for him, and occasionally relieved him of his writing duties.

Evidence collected by Eliot's bibliographers, William Baker and John C. Ross, does not rule out the prospect that Eliot wrote the Leader review. ${ }^{20}$ Baker and Ross state that Eliot "provided a string of relatively short articles and reviews for the Leader published between 17 March 1855 and 30 August 1856," and they calculate, "Between March 1855 and August 1856, GE recorded payment for 21 articles for the Leader, at $£ 1.1$ s apiece" $(421,428)$. Though the title "Transatlantic Latter-Day Poetry" does not appear in Lewes's or Eliot's notebooks, the notebooks' jottings are more anecdotal and partial than completely accurate records. That is, there is room for further investigation. Baker and Ross admit that their conclusions are necessarily provisional, that "attribution to her of items written during this time must remain 'plausible' rather than definite" (420). The uncertainty of these specialists regarding exactly which articles Eliot wrote during this period adds to the possibility that along with her other review essays, Eliot managed to write a second, longer review of Whitman's Leaves for the Leader in late May, 1856. There is also internal rhetorical evidence that the two reviews were written by the same author, which becomes apparent when the two reviews are closely read in tandem.

Along with their similar moderated endorsement of Whitman's achievement, a comparison of the Leaves of Grass reviews in the Westminster Review and the Leader reveals some shared idiosyncratic characteristics. The distinctive term "Transatlantic" is used in both reviews, 
for example. Furthermore, the Leader essay on Whitman happens to follow a discussion of Ruskin's Modern Painters, which Eliot reviewed enthusiastically in the same "Belles Lettres" column as Whitman's Leaves. As Thomas Pinney, the compiler of Eliot's essays has noted, it was not unusual for Eliot to review the same books for each periodical in two different essays. ${ }^{21}$ She admired John Ruskin, and had reviewed "Ruskin's Lectures" for the Leader two years earlier, on June 10, 1854. ${ }^{22}$ Even more relevant is the fact that Ruskin is on Eliot's mind in June 1856 , as demonstrated by an offhand comment she wrote that month to her friend Barbara Leigh Smith Bodichon-that, in her opinion, Ruskin "is the finest writer living." 23

There are some additional reasons for ascribing Eliot as the author of the June 1856 Leader review of Whitman's Leaves of Grass. Though he collected his editor's monthly stipends, Lewes did not write any other reviews while the couple was visiting the Welsh coast from early May to August in 1856, whereas Eliot was busy writing reviews for both the Westminster Review and the Leader the entire time. Furthermore, Lewes was a highly versatile thinker and writer who was capable of writing on a wide range of topics, but he had not previously demonstrated an interest in American poetry. Only one month before her review of Whitman's Leaves of Grass, however, Eliot reviewed Rufus Griswold's The Poets and Poetry of America. ${ }^{24}$ In her journal, Eliot records that she finished the Griswold review on February 19, 1856. The Leader printed her article eleven days later. ${ }^{25}$ Published in 1848, Griswold's collection of selected American poets could not have included Whitman's Leaves, which did not appear until 1855. Nevertheless, reviewing Griswold's American poetry collection probably piqued Eliot's interest in the subject, so that when Eliot was sent Whitman's volume the next month, she was predisposed to review it.

Rufus Griswold represents an interesting transatlantic connection between Whitman and Eliot, though he was a friend of neither. Griswold was among the earliest American reviewers of Whitman's book of poems. In her study of the poetry marketplace of Antebellum America, Susan Belasco calls Rufus Griswold an "influential" poetry critic, "who by the mid-1840s was making a significant name for himself as a compiler of successful anthologies of poetry." ${ }^{\prime 26}$ Instead of praising Whitman's Leaves of Grass, Griswold called it "a mass of stupid filth" and a "gross obscenity" unworthy of Emerson's esteem, and he ended the review with the Latin phrase "Peccatum illud horribile, inter Christianos non nominandum," which translates as "that horrible sin not to be named among Christians." 27 Griswold's comment, now notorious among Whitman scholars, represents the earliest explicit denunciation of the homoerotic element in Whitman's poetry. ${ }^{28}$ His use of the Latin phrase implies an understanding between the critic and his expected 
audience; Griswold used it with the assumption that readers not only would comprehend this inference about Whitman, but also that they would be repelled by it.

After reading Griswold's scathing review, however, Whitman found a way to use it to his advantage. As Heather Morton has reported, Griswold's contemptuous review of the 1855 Leaves was one of the newspaper clippings Whitman pasted into the books he sent to British reviewers. Morton's speculation about Whitman's motivation raises some interesting possibilities:

On one hand, the accusation of homosexual activity brought it to public attention and might have served as a form of social, albeit negative, recognition. If Whitman wanted to enfranchise men who experienced same-sex desire, advertise to them, this review would certainly have done the trick. Even those readers who strongly disapproved might be titillated into investigating what all the fuss was about, and there was the book, already in hand....The sexual scandals attending Byron's career had done nothing to diminish his readership-much the opposite. ${ }^{29}$

Morton's point is shrewd. It may be that Whitman was attempting to balance his own glowing reviews with a negative one to give the impression of a fair sample, but there were other negative reviews besides Griswold's he could have chosen. Griswold was alone among American reviewers in arguing that Leaves of Grass described sexual contact between men (and that it should be condemned for doing so). According to Eve Kosofsky Sedgwick and Joann P. Krieg, Leaves of Grass was recognized by British readers long before the Americans as involving same-sex eroticism. ${ }^{30}$ It is possible that Griswold got this notion from fellow staff writers at the Westminster Review where, by an interesting coincidence, Griswold contributed short reviews of American literature in $1852-1853 .{ }^{31}$

Even if the Griswold review was pasted into Eliot's review copy of Leaves of Grass, there is no way to determine whether or how this dubious supplement would have influenced her endorsement of Whitman. We are on firmer ground in stating that Eliot's positive impression would have been enhanced by reading Ralph Waldo Emerson's now-famous letter to Whitman greeting him at the beginning of a great career, a reprint of which also had been pasted into the books. ${ }^{32}$ Emerson's connections to Eliot and Emerson's connections to Whitman, respectively, have been examined by others, but their interesting triangular relation has not been previously noted. Eliot and many of her circle knew and esteemed Emerson. Emerson's recommendation of the unknown American poet certainly opened doors for Whitman at important British periodicals. ${ }^{33}$ And in Eliot's case, her personal appreciation of and attraction to Emerson (she called him "the first man [she had] ever seen") would have been 
a strong incentive for her to review Whitman's volume of poetry. ${ }^{34} \mathrm{Em}$ erson had not yet met Whitman in person when he wrote the new poet that crucial letter of praise. Whitman had heard Emerson's lecture on "Nature and the Powers of the Poet," which he had found inspirational. Emerson received one of the first copies of Whitman's newly printed Leaves of Grass. ${ }^{35}$ On receiving Emerson's enthusiastic reply, Whitman reprinted and circulated it. Without Emerson's letter of endorsement, the British literati likely never would have heard of Whitman.

Emerson's praise of Whitman during a lecture had another bolstering effect on Whitman's British reception when, long before Moncure Daniel Conway moved from his native America to London to become Whitman's unofficial British agent and greatest publicist, Conway was inspired by Emerson's lecture to seek out Whitman's poetry and the poet himself. ${ }^{36}$ As Whitman's primary literary agent in Britain, who published reviews on both sides of the Atlantic and tirelessly sought an English publisher for Whitman, Conway played a significant role in gaining recognition for Whitman and his work in Britain. What is more relevant here, however, is that both Emerson and Conway forged connections with Eliot and Lewes, whose access and influence with important British periodicals helped gain a foothold for Whitman's initial reception in Britain.

Like Whitman, Eliot had a connection with Emerson, but her relationship with the famous American essayist, lecturer, and poet was more personal than professional. Eliot met Emerson in 1848 at the home of two of her close friends, Charles and Cara Bray. They developed an instant rapport over their shared enthusiasm for Jean Jacques Rousseau's Confessions, which famously achieved a new level of candor in what could be admitted in an autobiography. ${ }^{37}$ Whitman, Emerson, and Eliot shared a passion for reading French literature, which was much franker than British or American writing, for example, in depicting human sexuality. ${ }^{38}$ They particularly admired George Sand and Jean Jacques Rousseau, but in their own writing, Emerson and Eliot were inclined to be far more conservative than Whitman was. Both Emerson and Eliot cautioned fellow writers to be more reticent about sexual subjects. Emerson specifically had advised Whitman to omit the frankly sexual poems from his 1860 edition of Leaves of Grass, a judgment with which Eliot surely would have concurred, given her disparagement of his "very bold expressions" and "unnecessary openness" in her 1856 reviews. There is no record of her response to Whitman's 1860 edition of Leaves, which some have viewed as sexually bolder for including the "Children of Adam" and "Calamus" sections. ${ }^{39}$ By then, Eliot had given up reviewing the creative works of others, and was writing them herself.

After 1857, Eliot withdrew almost completely from the world of periodical publications. She had turned her attention to writing fiction 
in September of 1856 and afterward wrote little else. This decision resulted in immediate and lasting literary success, which allowed Eliot and Lewes by 1863 to purchase a large London home, dubbed "the Priory," where they entertained intellectual friends and associates at Sunday afternoon salons for most of the next fifteen years, until Lewes's death. Their early years together were difficult for Eliot, who receded from the world of her professional peers as she became known as the woman who was living "in sin" with Lewes, a married man. Primarily to escape the consequences of having anyone associate her writing with the much-discussed scandal of her relations with Lewes, she decided to write all her fiction under the pseudonym "George Eliot." She believed the pen name, which she called the "iron mask of my incognito," was a necessary disguise - but painful too, because it required her to lie to her closest friends. ${ }^{40}$ By 1859, Eliot's first novel Adam Bede had catapulted her to stardom, and made her so rich and famous that her anonymity became impossible to maintain. Eliot evaded questions and clung to her story that she was not the author until an imposter began to claim unearned recognition and payment. Though fame and wealth helped mitigate the discomforting loss of privacy, exposure was not entirely positive. This contextualizing information will not be new to scholars of George Eliot, but it is important to explain Eliot's willingness to hide behind a protective lie in order to win social approbation. Fame, along with a strong aversion to biographers' curiosity about her, kept Eliot cautious about her public reputation. As Rosemarie Bodenheimer has demonstrated, Eliot was conscious of writing even her private letters for a wider public audience that was constantly judging her. ${ }^{41}$

Though Eliot's tendencies toward reticence are well established, a comment that she made about Whitman in April 1876 is nonetheless surprising, for it suggests that she had completely reversed her former appreciation of the poet. A simple reading - that Eliot rejected Whitman-does not take into consideration the constellation of circumstances and relationships that may have influenced her statement. Before turning to Eliot's 1876 pronouncement, some second-hand reports from mutual friends of Eliot and Whitman help illuminate what Eliot and Whitman thought of one another during the interim years between her positive reviews of his work in 1856 and her apparent rejection of it twenty years later.

Before 1868, Whitman's Leaves of Grass was known in England only among a relatively small but influential circle of the British literati, including Eliot, Lewes, and a cohort of other talented writers and artists, most of whom were their friends-Robert Buchanan, Alfred Lord Tennyson, John Addington Symonds, John Ruskin, Algernon Charles Swinburne, William Michael Rossetti, for example, along with some less famous intellectuals such as Henry Sidgwick, Oscar Browning, 
Frederick W. H. Myers, Richard Monkton Milnes (Lord Houghton), Roden Noel, Moncure Daniel Conway, and William Bell Scott. ${ }^{42}$ Scott was one of the first British readers of Whitman's 1855 Leaves, and because he was an old friend of Lewes, he may have been the conduit through which Eliot first noticed the work, which led to the reviews that helped spread the word that Whitman was a serious and important poet. Though Eliot won readers for Whitman by reviewing Leaves in prominent publications, Lewes also seems to have helped Whitman's British reception a great deal in the early years. It appears more than coincidental that Whitman enthusiasts placed their reviews and articles about Whitman in publications Lewes either edited or in which he had friends on staff. For example, as editor of the new Fortnightly Review, Lewes included essays by two of Whitman's most devoted disciples: Robert Buchanan, who had moved to London from Scotland, and the above-mentioned American expatriate Moncure Daniel Conway, whose enthusiastic essay reported on a personal meeting with Whitman in America.

By all accounts, the efforts of Eliot and Lewes on Whitman's behalf were small in comparison with the effect on Whitman's popularity and influence generated by the publication of William Michael Rossetti's 1868 British edition of Poems of Walt Whitman - a selection of the least controversial poems from the poet's 1867 American edition-which amounted to about half of the entire volume. In order to get past new British obscenity laws, Rossetti and his publisher John Camden Hotten ultimately chose to eliminate any "decidedly offensive" poems, including the "Children of Adam" and "Calamus" clusters (though Rossetti did print a few individual "Calamus" poems), the poem later called "Song of Myself," and many others. In his twenty-seven page "Prefatory Notice," Rossetti justified his editorial decisions: "My choice has proceeded upon two simple rules: first, to omit entirely every poem which could with any tolerable fairness be deemed offensive to the feelings of morals or propriety in this peculiarly nervous age; and, second, to include every remaining poem which appeared to me of conspicuous beauty or interest." ${ }^{43}$ Although Conway's role in promoting Whitman in Britain has been given surprisingly scant attention by Whitman scholars, ${ }^{44}$ William Michael Rossetti's contribution to Whitman's fame in Europe has been deservedly recognized. As one of the founding members of the Pre-Raphaelite brotherhood and an author of hundreds of literary essays, Rossetti's position within the literary establishment was well secured; his championing of Algernon Swinburne and Whitman against mid-Victorian prudery was especially important to the literary reputations of these poets who challenged the boundaries of literary (and sexual) conventions. ${ }^{45}$ On several occasions Whitman expressed 
frustration with Rossetti's editing. ${ }^{46}$ Nevertheless, Rossetti's careful selections, along with the efforts of Conway and Hotten, did help to secure immediate fame for Whitman in Britain and prompted readers to seek out Whitman's complete poems, where, if they desired, they could find the more radical Whitman. ${ }^{47}$

Whitman's most important female disciple, Anne Gilchrist, discovered Whitman through Rossetti's 1868 British edition, as did Edward Dowden, who became another energetic advocate for Whitman. ${ }^{48}$ Dowden and Gilchrist are two additional points of connection between Whitman and Eliot. In 1869, when he discovered Whitman's poetry, Dowden was a young Professor of Oratory and English Literature at Trinity College, Dublin, who was eager to make his mark on the literary scene. He wrote a perceptive and enthusiastic analytical essay on Leaves of Grass and sent it off to the Macmillan Magazine. As Harold Blodgett explains, Macmillan "refused Whitman summarily, although the editor, George Grove, was favorably disposed toward Dowden." Whitman was deemed too controversial for Macmillan. Then the Contemporary Review editor decided at the last moment, after agreeing to take Dowden's article, that it was "much too dangerous for their clerical clientele." ${ }^{\prime 49}$ Dowden ended up offering the piece free to the Westminster Review, where it finally appeared in July 1871.

While the majority of British periodicals continued to shun Whitman and his devotees, Dowden found fellow supporters among Eliot's and Lewes's circle, whose influence probably helped Dowden to place his article with the Westminster Review. In 1872, Dowden wrote an appreciative analysis of George Eliot's work-an essay that so delighted Lewes and Eliot that, when Dowden expressed interest in writing a complete biography of her, they considered it seriously (Haight, GEL, 5: 299-300; 6: 255n4)..$^{50}$ Though Dowden eventually abandoned the idea, Eliot's provisional acceptance of Dowden's plan is noteworthy because it was so uncharacteristic-Eliot actively resisted all other biographers and interviewers seeking personal information.

Anne Gilchrist also had connections with Lewes and Eliot. Gilchrist is known to Whitman scholars for "An Englishwoman's Estimate of Walt Whitman," an essay she compiled from the enthusiastic letters she wrote to William Michael Rossetti after she too read his 1868 Selected Poems of Walt Whitman. Gilchrist's essay, like Dowden's, demonstrates a discerning intellectual engagement with Whitman's poetry, while her private letters to Whitman reveal her deep emotional engagement with the poet behind the poetry. ${ }^{51}$ Gilchrist and Eliot did not meet in person, but they exchanged several friendly letters when Eliot and Lewes rented Gilchrist's country home at Shottermill in Surrey during the summer of 1871, before purchasing their own estate at Witley, Surrey. Gilchrist and Eliot were quite well known to one another and shared many of 
the same friends. Whitman noted another connection between the women - that Gilchrist was close to Mathilde Blind, who related to her much information about Eliot (Traubel 2: 438-439). Blind authored the first, full-length biography of Eliot in 1883, wherein she discusses the Gilchrist-Eliot connections and comments on Eliot's appreciation of Gilchrist's well-stocked library at the Shottermill residence. ${ }^{52}$ Gilchrist's biographer Elizabeth Porter Gould surmised that Eliot must have first read Leaves of Grass while renting Gilchrist's cottage, and she assumed that Gilchrist had a hand in introducing Eliot to Whitman's poetry. ${ }^{53}$ As Eliot's 1856 reviews show, Eliot actually encountered Whitman's poetry long before Gilchrist. No extant letters between Gilchrist and Eliot mention Whitman, but it is more likely that Gilchrist was a source of information for Whitman about Eliot than for Eliot about Whitman, judging, as we shall see, by Whitman's awareness of Eliot's personal circumstances.

Eliot's biographers rarely mention any Eliot-Whitman connections, and, when they do, they repeat Gould's mistaken supposition that Eliot must have learned about Whitman from Gilchrist. The lack of knowledge about these important transatlantic interrelationships is entirely understandable-Eliot's Leaves of Grass reviews were not signed, and they have never been included in collections of her essays. Another factor may be even more significant for our purposes of ferreting out Eliot's real opinions of Whitman. It seems that Eliot pretended not to know Whitman's work on at least one occasion when she was asked her opinion of it. In her biography of Eliot, Blind relates that when a literary friend recommended Whitman's works to Eliot, she told him she was hesitant to read it "on the ground of [Whitman's] not containing anything spiritually needful for her." Blind reports that Eliot later told this (unnamed) friend that since they had first spoken of Whitman's poetry, she had been induced to read it, and had as a result "changed her opinion and admitted that [Whitman] did contain what was 'good for her soul"' (146).

This same narrative was told to Whitman by H. Buxton Forman several years after it occurred, and, from this retelling, we learn important contextual details. Forman claims he asked Eliot directly "what she thought of L. of G." at one of her regular Sunday afternoon soirees in her home, "probably around 1871." Significantly, Forman says he managed to capture her attention during "one of those short earnest tête-a-têtes that she found means to accord somehow to each of her room full of visitors" (Traubel 2: 433-34). Forman's report of Eliot's answer corroborates Blind's account: after finding "she knew hardly anything of L. of G.," Forman urged her to read it, to which Eliot disclaimed, "she had glanced at it but was impressed that it had 'no great 
message for her soul."' Only privately, in a follow-up letter, did Eliot admit that she was reading Leaves, and found the book had a "message for her soul." Here Forman adds that Eliot also praised the book for "its scope, meaning, and original force," but he was unprepared to have those words quoted, because they were "only reported to me by a tolerably accurate young man" (Traubel 2: 433-34).

The first thing to be learned from this story is that Whitman's British friends were paying close attention to what Britain's most famous novelist in the 1870s was saying about Whitman, and they were discussing her reaction among themselves. Forman passes along to Whitman his own account as well as another one from this "tolerably accurate young man." Whitman assures Traubel that Forman's reports of Eliot's admiration for Leaves were consistent with "similar intimations given by other people who knew her in London" (2: 433-34). Neither Dowden nor Gilchrist could claim to have introduced Whitman's works to Eliot, but they were among several mutual friends who related to Whitman that Eliot admired him. When Traubel asked Whitman directly whether Eliot had ever written him a letter, Whitman told him that she never did. Perhaps she feared he would reprint her letter without her permission and paste it into the flyleaf of his next edition, as Whitman had done with Emerson's letter. By this point, a letter from Eliot would have been at least as influential as Emerson's; because Leaves of Grass was so controversial, Whitman and his supporters were keen to have Eliot's public endorsement, which would be

a precious war-weapon when you consider the immense estimation in which George Eliot is held, especially by the enemy. . . . It is high jinks [sic] for us when she, whom they are even ranking with Shakespeare, should put L. of G. among the few good modern books she read, and declare that she found it "good for her soul!" This must be wormwood to some of our moral literary ghosts - ghosts, indeed, since they have, if you'll believe them, got rid of their bodies before death-who are always retching over L. of G., and purring like cats over Adam Bede and Middlemarch. A careful advertisement ought to be prepared for McKay [Whitman's publisher], giving a few of the best opinions on L. of G., with this prominent among them. The effect would be considerable. How poor Sidney Lanier would wince over this testimony! He had a savage (and silly) attack on you in his lectures, coupled with sky-faulting eulogy of George Eliot. To see his idol prostrate in worship before his béte noir would have been a stinger. But, rest his soul! he's dead, and gone where he knows what an ass he made of himself. (Traubel 3: 128)

This letter to Whitman from one of his best American promoters, William Douglas O'Connor, shows how enormously influential a tribute from Eliot would be, and how any words of praise by her would be used against Whitman's perceived enemies on both sides of the Atlantic. 
Another conclusion one can draw from this well-circulated story of Eliot's apparent denial of any knowledge of Whitman is that Eliot's comments regarding the controversial poet changed dramatically, depending on whether she thought she was making a public or a private declaration. During Forman's interview, as he states, Eliot was entertaining a room full of guests. During the early 1870 s, a regular Sunday salon was orchestrated by Lewes to enhance and enshrine Eliot's literary celebrity. ${ }^{54}$ Recollections by other frequent guests serve to illustrate the context in which Eliot's response to Forman's question should be viewed. Sidney Colvin, who attended the salons often in the early 1870 s, noted that Lewes directed visitors to Eliot, the "presiding genius," as if to the Oracle:

If it had been her nature to seek equality of regard and companionship from those visitors who came about her, Lewes, I think, would have hardly made it possible... adoration, homage, was what he seemed to expect for her from all who came about them. He never encouraged the conversation among the Sunday guests in the room to become equal or general, or allowed one of them to absorb her attention for very long, but would bring up one after another to have his or her share of it in turn, so that if any of us began to feel that talk with her was taking an easier and closer turn than usual, the next thing was that it was sure to be interrupted. ${ }^{55}$

Colvin's description is corroborated by others' recollections, including that of Sir Frederick Pollock, who, according to Collins, similarly "traced the one-at-a-time rule to GHL's protectiveness, believing it spoiled GE's talk." Eugenie Hamerton was another Priory visitor who noted that "Mr. Lewes offered tea himself, because the worshippers surrounded the Idol so closely that they kept her prisoner within a double circle, and they were so eager for a few words from her lips, that as soon as she moved a step or two, they crowded about her in a way to make me think that in a small way and in her own drawing room, she was mobbed like a queen at some public ceremony" (Collins 92-93). Affected by the pressure to speak words of wisdom that might be quoted and discussed, it is hardly surprising that Eliot might cautiously pretend to know almost nothing of Whitman or the scandal his poetry was causing in Britain's literary circles. As the presiding moral sage whose visitors hung on her every word, Eliot would have been understandably guarded. It seems unlikely Eliot would forget she had reviewed Whitman's first edition of poems; nevertheless, when she was asked specifically about Whitman in company, her first impulse was to discount him. Only in a follow-up private letter to her interviewer did she admit to admiring Whitman's poetry. Whether or not Eliot or her group of friends associated Whitman with same-sex love, there was controversy enough regarding Whitman's frank depiction of male-female sexuality to have influenced Britain's 
most popular literary celebrity in the 1870 s to withhold commentary. Moreover, the politically astute Lewes seems to have prevailed upon his partner to hold her tongue.

Whitman certainly thought so. Whitman was delighted that "people who knew her in London" told him she was on his side; he held, however, that her appreciation was genuine but not wholehearted, and added that " "But while I might have some message for her soul, as she said, I do not think that as a whole I would ingratiate myself in her affections. We stood for the same things up to a certain point but there parted company, she to look back and around, I to look ahead"' (Traubel 2: 433-34). Whitman noticed Eliot's lack of courage in defending him, as he later elaborated to Traubel:

I am sure George Eliot had an affinity for me-some impulse in her own nature towards me. Mrs. Gilchrist more than once spoke to me about it: she knew Mathilde Blind and knew from her many things about George Eliot. Then I am sure George Eliot was tampered with: her instincts, her large vision, her rich nature all through, rebelled against, appealed from, restriction. But she lived in the midst of crowding conventions, in relations with those who at the end tried to explain away any preference she may have shown for me. She once adopted a motto from the Leaves and more than one of her friends have made some show as if to apologize for it. (2: 438-39)

Whitman never met Eliot, but this comment about her demonstrates he was highly perceptive about her character and circumstances. $\mathrm{He}$ recognized that "her instincts, her large vision, her rich nature" would have embraced him but that she was constrained by "crowding conventions" and ultimately "tampered with." Whitman perceives that Eliot would not give her true opinion to Forman when Lewes was present. Forman told Whitman that Lewes had been listening in, and when he heard Forman's question about Whitman, he interjected with a flippant comment about Whitman as the author of "Heel Taps" (a pun, of course, on the title of Whitman's then-recently-published Drum Taps) (Traubel 2: 445). Whitman blames Lewes for Eliot's reluctance to support him, and tells Traubel, "There is no doubt if she had had a perfectly free pen she would have made some acknowledgment to me in the key of Forman's allusion to her. But she was nullified - by Lewes, first-then by her second husband, Cross" (2: 445). Neither Lewes nor Cross were Puritans in any sense - they were, however, enormously influential in establishing and maintaining Eliot's reputation as a moral guide in the eyes of the Victorian reading public.

Whitman's guess about Lewes's role in Eliot's reluctance to support him publicly was insightful. Lewes may be viewed as excessively controlling (or especially supportive, depending on one's perspective); in his assumed roles as literary agent and publicist, Lewes not only stage- 
managed Sunday afternoon salons, as we have seen, but also managed Eliot's income, read and sometimes answered her mail, defended her from interruptions, prevented her from reading reviews of her work, and actively guarded her literary reputation. Eliot characteristically deferred to Lewes's judgment, particularly his career advice; after all, their partnership was making them famous, sought after, and wealthy beyond their wildest hopes. Behind Lewes's suggestion that quoted lines of Whitman's poetry should not appear in Eliot's new novel may be the inference that she should avoid any connection with Whitman that the public could view as an endorsement. Though Eliot concurred, it was Lewes's rereading of the manuscript of her new novel, Daniel Deronda, that prompted Eliot to write to her publisher, John Blackwood, on April 18,1876 , to ask whether a chapter epigram that quoted Whitman could be removed:

We are rather vexed, now it is too late, that I did not carry out a sort of incipient intention to expunge a motto from Walt Whitman which I inserted in Book IV. Of course, the whole is irrevocable by this time, but I should have otherwise thought it worth while to have a new page, not because the motto itself is objectionable to me-it was one of the finer things which had clung to me from among his writings-but because, since I quote so few poets, my selection of a motto from Walt Whitman might be taken as a sign of a special admiration which I am very far from feeling. How imperfectly one's mind acts in proof reading! Mr. Lewes had taken up Book IV yesterday to re-read it for his pleasure merely, and though he had read it several times before, he never till yesterday made a remark against taking a motto from Walt Whitman. I, again, had continually had an 'appetency' towards removing the motto and had never carried it out-perhaps from that sort of flaccidity which comes over me about what has been done, when I am occupied with what is being done. (Haight, GEL, 6: 240-41)

Eliot had selected two lines of Whitman's "Voices" (later retitled "Vocalism") as an epigraph for Chapter 29 of her recently completed novel, Daniel Deronda: "Surely whoever speaks to me in the right voice, him or her I shall follow, / As the water follows the moon, silently, with fluid steps anywhere around the globe. ${ }^{" 56}$ Her qualms about choosing these lines did not stem from any sense that the lines themselves were inappropriate, she said, but because "my selection of a motto from Walt Whitman might be taken as a sign of special admiration, which I am very far from feeling." That is, Eliot said she regretted choosing lines ascribed to Whitman because she did not want to be accused of admiring him. This apparent rejection of Whitman, not for his poetry but for his reputation, was written to her conservative Christian publisher, whereas the message that Whitman was "good for her soul" was reportedly expressed to H. Buxton Forman, one of Whitman's enthusiastic supporters. Did Eliot have a change of heart about Whitman, or might we read her rejection as a sign of deference to the two men who man- 
aged her career? Eliot complied with Lewes's suggestion that she write Blackwood to determine whether it might still be possible to remove the brief lines of Whitman's poetry from Daniel Deronda. It was too late to make changes for that printing. It is worth noting, however, that when Eliot did have an opportunity to revise the work for the Cabinet Edition reprinting, she left Whitman's lines intact. This fact helps to support the possibility that Eliot asked Blackwood to remove Whitman's lines in order to appease Lewes, while her own inclination was to retain Whitman's words.

Gordon Haight appears to be the only scholar to supply a reason for Eliot's rejection of Whitman. In a brief editorial note accompanying Eliot's April 18, 1876, letter to Blackwood, Haight suggests that her statement against the poet may have been related to a harshly negative article titled "Walt Whitman" published anonymously in the Saturday Review on March 18, 1876. The article introduces Whitman as "an American writer who some years back attracted attention by a volume of so-called poems which were chiefly remarkable for their absurd extravagance and shameless obscenity, and who has since, we are glad to say, been little heard of among decent people." It goes on to rebuke the "small coterie of persons in this country who are not ashamed to confess their liking for Whitman's nastiness, [while] his own countrymen have universally repudiated him" and charges that Whitman's poverty is no more than he deserves for tying his living to such a sordid subject. ${ }^{57}$ In late January and through February and March of 1876, the controversy about Whitman in Britain was reignited in the British press, especially after Robert Buchanan and William Michael Rossetti initiated a campaign in the London Daily News encouraging Whitman's British fans to support Whitman in his time of need. As we have seen, Eliot and Lewes could have been identified in conjunction with this "coterie" of Whitman supporters who were being called out for their unashamed association with "Whitman's nastiness." The debate was emotionally charged, and Eliot's comments to Blackwood may indicate that she was intimidated by the scandal. Eliot's response to Whitman was surely influenced by the recent bad publicity, but the situation was more complicated and nuanced than Haight's short editorial note suggests.

Before one accepts Eliot's letter to her publisher John Blackwood as indicative of her total rejection of Whitman, it is important to consider the letter's audience as well. The context of Eliot's long relationship with her publisher influenced what she would have been willing to tell him. Through Lewes, Blackwood encouraged Eliot's first steps into a fiction-writing career, before he knew anything about her. He allowed her to reveal herself on her own terms and even after he discovered that his new author was a social outcast hiding behind a pen name, 
Blackwood kept her identity secret. Though he was himself a conservative and devout member of the Church of England, he did not judge Eliot for living unmarried with Lewes. Through two years of mounting pressure to reveal her identity, Blackwood gave away nothing to curious biographers. Because Blackwood's publishing company was based in Edinburgh, Scotland, rather than in London, the business associates did not see one another often; nevertheless, they developed a strong relationship over the years through regular letters and occasional visits - a friendship based on mutual benefit. Blackwood published all of Eliot's novels except one; when she decided to sell Romola to a higher bid from another publisher, Blackwood blamed her "defection" on "the voracity of Lewes" (Haight, GEL, 4:38). As Nancy Henry has argued, their "defection" was actually a sound business decision on the part of a successful couple, though Eliot felt tremendously guilty for leaving Blackwood and was happy to publish all her subsequent work with Blackwood's firm. ${ }^{58}$ For many years, Lewes and Blackwood cooperated as the guardians of Eliot's celebrity status. Her writing did make both men wealthy, but it was partly for this reason that she deferred to them-their plans for her succeeded. In 1870, after a long conversation with Eliot, Blackwood wrote to his brother "I shall always regard and esteem her" (Haight, GEL, 5: 99). The respect and esteem went both ways; he was like a substitute older brother whose approval she sought, which is not necessarily the same as a confidante with whom she could bare her soul. For all these reasons, it is possible to read Eliot's letter condemning Whitman as a white lie, written to assure her publisher and dear friend Blackwood that she did not intend to join the controversy surrounding Whitman, the bard of the body. Interpretation of Eliot's statement is incomplete without context.

Eliot knew what it felt like at the center of a storm of scandal, because that was her own experience after she began living with the already-married Lewes in 1854. Though Eliot wanted to be known as Lewes's wife, for years many people considered her Lewes's mistress-a woman respectable folks did not invite to dinner. Naturally, she deeply resented the demeaning social position she was cast into by gossips. In order to protect herself as much as possible from social barbs, Eliot took refuge in the appearance of conventionality - to the extent that she wore a wedding ring, called the relationship a marriage, and asked to be called "Mrs. Lewes." Even after she became the highest paid and most popular author in Britain during the 1870s, Eliot's public conventionality and reserve was renowned. Eliot was notorious for her extreme sensitivity to public opinion and her intense consciousness of her reputation. Rosemarie Bodenheimer has established convincingly that Eliot's acts of scorn and defiance of conventional morality were 
followed regularly by a retreat from all possible controversy and a reestablishing of herself as a model of goodness and propriety, and that this pattern is one of the most dominant aspects of her behavior and her writing (xiv-xv).

As she grew older and more famous, Eliot became increasingly cautious about self-revelation, which she feared could be misconstrued and turned against her. She was especially evasive about her past and attempted to obscure it by burning most of the letters her friends sent to her: "I have destroyed almost all my friends' letters to me simply... because they were only intended for my eyes, and could only fall into the hands of persons who knew little of the writers, if I allowed them to remain after my death" (Haight, GEL, 3: 376). In another letter Eliot says she has decided to burn some of her letters and papers to prevent them from being "read with hard curiosity" by biographers who publish personal information that ought to remain private and she adds, "I am continually considering whether I have saved as much as possible from this desecrating fate" (Haight, GEL, 7: 341). She became increasingly fearful of biographers whom she imagined rummaging through her desk after she was gone, looking for scandalous bits and not bothering to read her works. Her belief in "sacred silence" and her expressed desire in her review of Leaves of Grass that Whitman would have left "the veil across the Temple" of certain aspects of human experience may be read as a projection of her own defensive reticence.

While Eliot ultimately gained a sanitized reputation as a moral sage, Whitman's reputation for being earthy, free, sensual, and expressive continued to grow. Eliot may have appreciated Whitman's "barbaric yawp," but by 1876, she could no longer express this affiliation. By the mid-1870s, the climate of Victorian sexual politics had become more repressive, and to maintain Eliot's fame, she and Lewes had to become more vigilant about their public reputations, which included what they wrote or said in the company of all but their closest friends. In their historical moment, personal statements were highly politicized. Then again, perhaps times have not changed so much as we would wish. Eliot's self-concealment and resistance to public expressions of "unnecessary openness"; her willingness to be guided by Lewes's business sense; and her desire to sustain Blackwood's high opinion of her, taken together, add necessary context for reading Eliot's rejection of Whitman in 1876. The negative publicity generated against Whitman by the Saturday Review in the previous weeks, combined with a concern for maintaining Eliot's celebrity status, also contributed to her increasingly cautious response to the ever-incendiary Whitman. At a time when the moral requirements of art were generating fierce debate, Eliot retreated from Whitman, the too-bold spokesperson for sexual freedoms. 
But did she also retreat from Whitman because she recognized him as a representative of same-sex desire? This hypothesis is much less certain. Nevertheless, this essay has established that Eliot saw Rufus Griswold's review-the first to condemn Whitman's poetry for describing the unmentionable sin of same-sex desire; that Eliot and Lewes were friends with a large number of Whitman's early British supporters; and that many of these individuals who were writing to Whitman were also members of what Kathleen McCormack has identified as "the substantial gay and lesbian contingent" that visited Lewes's and Eliot's Sunday afternoon salons (3). McCormack's research into the dynamics of same-sex alliances of Eliot's and Lewes's correspondents, visitors, or friends is illuminating. She uses the examples of Eliot's interactions with three close friends-Oscar Browning, Frederick Meyers, and Edith Simcox-to "indicate that George Eliot refused to condemn the acts or inclinations of her gay and lesbian friends" (99-105). Nancy Henry asserts that Eliot's research, particularly into the fifteenth-century's Italian Renaissance culture, would have instructed her in the history of homosexual culture: "Eliot's knowledge of homosexuality-and boldness in representing it (however coded) - should not surprise us. References to love and sex between men abound in the literature she read while researching this period, and her allusions to homosexuality in Romola are continuous with her explorations of the complex and various forms of gender and sexuality throughout her work" (329). Finally, Henry is not the only Eliot scholar to recognize that interactions between many of Eliot's male characters seem sexually charged..$^{59}$ While Eliot never commented explicitly about same-sex desire in her letters or in her fiction, there is a general consensus among critics who have written on the subject that the expression of same-sex desire is normalized (but coded, usually in spiritual terms) in Eliot's works as part of every society. The fiction shows that when "otherness" is embraced, individuals broaden their self-understanding and communities are enhanced when they accommodate difference.

Whether or not she knew anything about Whitman's sexuality specifically, it is clear that Eliot did not reject others on the basis of whom they loved. In addition to all the reasons this essay has discussed, Eliot's retreat from Whitman was an attempt to shield her work from condemnation. Daniel Deronda, the novel Eliot feared would be harmed by overt reference to Whitman in 1876, is the text that has garnered more queer readings than any of her others. Unfortunately, George Eliot never knew her appreciation of Walt Whitman and her coded representation of "enthusiastic bachelors" would someday be celebrated rather than condemned.

\section{University of Nebraska-Lincoln}




\section{NOTES}

1 The major studies of Whitman's British reception are: Clara Barrus, Whitman and Burroughs: Comrades (Boston and New York: Houghton Mifflin, 1931); Harold Blodgett, Walt Whitman in England (Ithaca, N.Y.: Cornell University Press, 1934); Eve Kosofsky Sedgwick, "Toward the Twentieth Century: English Readers of Whitman," in Between Men: English Literature and Male Homosocial Desire (New York: Columbia University Press, 1985), 201-218, hereafter, "Toward the Twentieth Century"; M. Wynn Thomas, Transatlantic Connections: Whitman U.S., Whitman U.K. (Iowa City: University of Iowa Press, 2005); Joann P. Krieg, Whitman and the Irish (Iowa City: University of Iowa Press, 2000), hereafter Whitman and the Irish; Betsy Erkkila, Walt Whitman Among the French: Poet and Myth (Princeton: Princeton University Press, 1980); and Michael Robertson, Worshipping Walt: The Whitman Disciples (Princeton: Princeton University Press, 2008).

2 Nancy Henry, “The Romola Code: 'Men of Appetites' in George Eliot's Historical Novel," Victorian Literature and Culture 39.2 (2011), hereafter, "The Romola Code"; Kathleen McCormack, George Eliot in Society: Travels Abroad and Sundays at the Priory (Columbus: The Ohio State University Press, 2013), hereafter, George Eliot in Society; Laura Callanan, “The Seduction of Daniel Deronda," Women's Writing: The Elizabethan to Victorian Period 3.2 (1996), 177-188; and Dennis S. Gouws, "George Eliot's 'Enthusiastic Bachelors': Topical Fictional Accounts of Nineteenth-Century Homoerotic Christian Masculinities and the Manhood Question," Forum on Public Policy: A Fournal of the Oxford Round Table 2 (2008), 1-16; hereafter, "Enthusiastic Bachelors."

3 The best examination of George Eliot's and George Henry Lewes's social circle is McCormack's George Eliot in Society. Details of George Eliot's and George Henry Lewes's journalism and editorial positions are recorded in William Baker and John C. Ross, eds., George Eliot: A Bibliographical History (Newcastle, Delaware: Oak Knoll Press and London: The British Library, 2002).

4 John Chapman, then the owner of the Westminster Review, took credit officially as its editor, though George Eliot specialists agree that she was the managing or de facto editor.

5 For detailed and informative discussions of the contemporary British reviews, see Kenneth M. Price's "Introduction," in Walt Whitman: The Contemporary Reviews (Cambridge [England]; New York, N.Y.: Cambridge University Press, 1996); and Brett Barney, Amanda Gailey, et al, "Sixty-Eight Previously Uncollected Reviews of Walt Whitman," Walt Whitman Quarterly Review 25 (Summer 2007), 1-76. Available on the Walt Whitman Archive (whitmanarchive.org).

6 Anonymous, "Leaves of Grass," Saturday Review 1 (March 15, 1856), 393-394. This first British notice, whose author remains unidentified, appeared two weeks earlier than George Eliot's. Available on the Walt Whitman Archive (whitmanarchive.org).

7 See Ed Folsom, "A Previously Unknown 1855 Albion Notice: Whitman Outed as His Own Reviewer," Walt Whitman Quarterly Review 27 (Summer/Fall 2009), 78-80.

8 In Kenneth Price and Charles B. Green's “Two Uncollected Early Reviews of the 1855 and 1856 Editions of Leaves of Grass," Walt Whitman Quarterly Review 18 (Summer/Fall 2000), 76-80, this review is attributed to George Eliot, with the acknowledgment that while Eliot scholars were aware she wrote it, Whitman scholars had not previously mentioned it. Eliot's notice of Whitman appeared in "Art and Belles Lettres" in the London edition of the Westminster Review 9 (April 1, 1856), 625-650, and was 
reprinted in the Westminster Review (American Edition) 42, no. 2 (April 1856), 343356. Eliot's review is available on the Walt Whitman Archive (whitmanarchive.org).

9 The injustice of social prejudice was a personal frustration for Eliot during the time she was writing this review, for after freely traveling together in Germany, she and Lewes had returned to conservative Victorian England to live together unmarried and found themselves the center of a whirlwind of scandal. In September 1855, she wrote a now-famous letter to her former best friend, Cara Bray, defending her disreputable behavior as "serious," not flighty: "Women who are satisfied with such [loose] ties do not act as I have done - they obtain what they desire and are still invited to dinner." In January 1856, the loss of Cara's friendship was still painful, as her letter to Cara's husband Charles Bray suggests. See, for example, George Eliot's letters "To Mrs. Charles Bray, 4 September [1855]" and "To Charles Bray, 1 January 1856," in Selections from George Eliot's Letters, ed. Gordon S. Haight (New Haven: Yale University Press, 1985), 151-154; hereafter, Selections from George Eliot's Letters.

10 "This information appears at the beginning of Eliot's review article, "The Antigone and Its Moral," Leader 7, no. 314 [March 29, 1856], 306.

11 For a nuanced discussion of Eliot's philosophy as expressed in "The Antigone and Its Moral," see Kathryn Brigger Kruger's “"The Antigone and its Moral': George Eliot's Antigonean Considerations," The George Eliot Review 43 (2012), 69-80.

12 Reprinted in Essays of George Eliot, ed. Thomas Pinney (New York: Columbia University Press, 1963), 261-265; hereafter, Essays.

13 “Transatlantic Latter-Day Poetry." Leader 7 (June 7, 1856), 547-548. Available on the Walt Whitman Archive (whitmanarchive.org).

14 Walt Whitman, Leaves of Grass (1855), 29. Available on the Walt Whitman Archive (whitmanarchive.org).

15 Brett Barney, Amanda Gailey, et al., "Sixty-Eight Previously Uncollected Reviews of Walt Whitman," Walt Whitman Quarterly Review 25, (Summer/Fall 2007), 1-76. Based on this research (conducted during my tenure as an editorial assistant at the Walt Whitman Archive, 2008-2012), the Whitman Archive's attribution for this review was updated on October 3, 2009, to "George Henry Lewes or George Eliot."

16 Edward Dowden, "Addenda: English Critics on Walt Whitman," in Richard Maurice Bucke, Walt Whitman (Philadelphia: Wilson \& McCormick, 1884), 236-255.

17 For example, an article entitled “Ruskin's Lectures" (Leader, 5 [June 10, 1854], 545-546) is identified by Gordon S. Haight "as one which [Lewes] was supposed to write, but that in fact George Eliot wrote when Lewes was taken ill in the late spring of 1854"; George Eliot: A Biography. (New York: Oxford University Press, 1968), 144; hereafter, George Eliot: A Biography.

18 “To Charles Bray, 6 June 1856," in George Eliot Letters, 9 vols., ed. Gordon S. Haight (New Haven and London: Yale UP and Oxford University Press, 1955), 2:252-253; hereafter, GEL.

19 Eliot's periodical contributions (including more than twenty articles and reviews published in the Leader between 1854-1856, two long essays and seven successive "Belles Lettres" reviews published in the Westminster Review in 1855-1856, two articles in Fraser's Magazine in June and July 1855, and three in Saturday Review in April, May, and September 1856) are documented in Baker and Ross, A Bibliographical History. Although Lewes was a regular Leader contributor, in spring and summer of 1854, for 
example, Eliot wrote all his regular columns because he was ill and ordered to take a "rest cure" (Baker and Ross 421). Baker's and Ross' finding suggests there was a precedent for Eliot taking over for Lewes again in the spring of 1856. Furthermore, from 1865-1868, when Lewes acted as adviser for George Smith's Pall Mall Gazette and as editor of the Fortnightly Review, Eliot contributed four articles to the former and two to the latter "to support him"; there are no indications that she was paid for these contributions (Baker and Ross 419).

20 On the contrary, in a personal email exchange (February 14, 2012), Professor Baker warmly encouraged this research and suggested possible sources of further information.

21 Pinney observes, "The books she reviewed for the Leader she was often able to notice a second time in her 'Belle Lettres' review for the Westminster; by this convenient device her work was made to yield double returns, though... she was always careful to avoid repeating herself in form if not in substance." In his introduction to his Essays of George Eliot, Pinney claims Eliot wrote thirty-three articles for the Leader, nine of which are reprinted in this collection. In his comments on Eliot's essay "The Natural History of German Life," Westminster Review (July 18, 1856), which began as a review of Wilhelm von Riel's books, Pinney mentions her April 1856 review of Ruskin's Modern Painters III (the review in which she also mentions Whitman) $(5,266)$.

22 Haight attributes this review to Eliot in George Eliot: A Biography, 144.

23 Haight, “To Barbara Leigh Smith, 13 June 1856," Selections from George Eliot's Letters, 155-156.

24 Rufus Wilmot Griswold, ed., The Poets and Poetry of America (Philadelphia: Carey and Hart, 1848).

25 Eliot mentions working on Griswold in her journal and notes that she completed her review on February 19, 1856 (Margaret Harris and Judith Johnson, eds., The Fournals of George Eliot [Cambridge: Cambridge University Press, 1998], 59). This resulting article was published as "The Poets and Poetry of America," Leader 7 (March 1, 1856), 306. Soon after, Eliot published "The Antigone and Its Moral" in the Leader Clearly, Eliot was a very frequent-if not a "regular"-reviewer for the Leader in 1856.

26 Susan Belasco, "The Poetry Marketplace of Antebellum America," in Leaves of Grass: The Sesquicentennial Essays, ed. Susan Belasco, Ed Folsom, Kenneth M. Price (Lincoln: University of Nebraska Press, 2008), 184.

27 Kenneth M. Price, in Walt Whitman: The Contemporary Reviews (Cambridge: Cambridge University Press, 1996), attaches an editorial note to the review translating Griswold's Latin phrase as "that horrible sin not to be named among Christians." Griswold's review, published November 10, 1855, in the New York Criterion, is available on the Walt Whitman Archive (whitmanarchive.org).

28 See Kenneth M. Price, To Walt Whitman, America (Chapel Hill: University of North Carolina Press, 2004), especially chapter four, "Transatlantic Homoerotic Whitman," in which Price notes that the British recognized the homosexual elements of Whitman's poetry long before Americans did.

29 Heather Morton, "Democracy, Self-Reviews and the 1855 Leaves of Grass," Virginia Quarterly Review 8 (Spring 2005), 229-243.

30 For example, in reference to the formation of groups of like-minded men in Britain in the 1870s, Joann Krieg notes, "Among the English writers and critics of 
the time, references to things 'Greek' in literature were often coded references to homosexuality, a word that had not yet come into being." In addition to John Addington Symonds' suspicions about Whitman, Krieg adds, "Wilde's use of the term ["Greek"] to describe Whitman's poetry may indicate that he had already formed an opinion as to the poet's sexuality" (Whitman and the Irish 169). Available on the Walt Whitman Archive (whitmanarchive.org).

31 Rosemary Ashton, 142 Strand: A Radical Address in Victorian London, (London: Chatto \& Windus, 2006), 119, 305.

32 The first British Leaves review in the Saturday Review, for example, describes the notices glued into the book. This review also quotes Emerson's letter in its entirety, along with selections from other American notices that had been pasted into the volumes distributed in England. Anonymous, "Leaves of Grass," Saturday Review 1 (March 15, 1856), 393-394. Available on the Walt Whitman Archive (whitmanarchive. org). Many other British reviews state, most with incredulity, that Ralph Waldo Emerson personally endorsed Leaves of Grass.

33 A majority of contemporary British reviews, both positive and negative, mention Emerson's letter of recommendation. See Kenneth M. Price's Walt Whitman: The Contemporary Reviews, or search all reviews of Whitman's work at the Walt Whitman Archive (whitmanarchive.org).

34 George Eliot to Sara Hennell, July 14, 1848: "I have seen Emerson-the first man I have ever seen" (GEL 1:270-271). Gordon Haight adds that Emerson "was much struck with" George Eliot and remarked, "'That lady has a calm, serious soul,'-and regretted very much he had no more time to stay amongst us" (GEL 1:271n6).

35 According to Jerome Loving, "It was during his lecture on 'The Times' in New York City in March of 1842 that Emerson first came in contact with Whitman, who heard him deliver 'Nature and the Powers of the Poet.' As editor of the New York $A u$ rora, Whitman wrote that Emerson's lecture was one of the richest and most beautiful compositions he had ever heard anywhere, at any time"; see "Emerson, Ralph Waldo [1809-1882]," in Walt Whitman: An Encyclopedia (New York: Garland Publishing, 1998), reproduced on the Walt Whitman Archive (whitmanarchive.org).

36 Conway moved to London in 1863, where he met and shared his enthusiasm for Whitman with a number of Whitman's early British supporters, including Lewes, who was instrumental in getting Conway's essays about Whitman printed in the Leader and the Fortnightly Review. Another connection between Whitman, Lewes, and Conway was William Bell Scott, a poet, painter, and fervent admirer of P. B. Shelley, whom all three men idolized. Details about Bell Scott's intense friendship with Lewes are detailed in his review of Sir Walter Scott's "Chorea Sancti Viti" in the July 5, 1851, Leader, in which he reminisces about their youthful friendship and their ambitions to become great philosophers. William Bell Scott purchased and distributed the 1855 edition of Leaves of Grass to his friends, including Conway, the Rossettis, and very likely to Lewes and Eliot.

37 Rousseau's confessions of unusual sexual preferences can seem surprisingly explicit even today.

38 Roger Asselineau, in "When Walt Whitman was a Parisian," (Mickle Street Review 9 [Part 2, 1988], 30-34), suggests that Whitman deeply sympathized with the French both for political reasons and for their frankness about sexual matters. In With Walt Whitman in Camden (WWC), Horace Traubel reports that Whitman told him, "I never 
took any stock in the ordinary disposition to cry down French life" (WWC 5: 349). On another occasion, he added, "I am aware of what our Puritans think of the French; it counts for little with me.... [t] he main difference between us and the French in sex directions is their frankness as opposed to our hypocrisy" (WWC 4:218). Traubel, With Walt Whitman in Camden, Vol. 4, ed. Sculley Bradley (Philadelphia: University of Pennsylvania Press, 1953); Vol. 5, ed. Gertrude Traubel (Carbondale: Southern Illinois University Press, 1964).

39 Whether the first edition of Leaves of Grass was bolder or tamer than the 1860 edition is still being debated by scholars of Whitman's sexuality. See, for example, Betsy Erkkila, "Songs of Male Intimacy and Love: An Afterword" in Walt Whitman's Songs of Male Intimacy and Love: 'Live Oak, with Moss' and 'Calamus' (Iowa City: University of Iowa Press, 2011), 99-162, where she elucidates both sides of the debate and provides extensive references for those critics currently engaging in this ongoing conversation.

40 Eliot refers to "the iron mask of my incognito" which prevents her from responding personally to Charles Dickens' praise of her fiction (Haight, GEL 2:424).

41 It is generally agreed among scholars of George Eliot that the most penetrating analysis of her correspondence is Rosemarie Bodenheimer's The Real Life of Mary Ann Evans: George Eliot, Her Letters and Fiction (Ithaca: Cornell University Press, 1996); hereafter, The Real Life. Even the newest biography of George Eliot, Nancy Henry's The Life of George Eliot (Malden, MA: Wiley-Blackwell, 2012), relies on Bodenheimer's analysis as a foundational study for all subsequent interpretations of Eliot's writing; hereafter, The Life of George Eliot.

42 Although it is not the intent of this essay to determine whether or which of these individuals expressed same-sex desire, the study of their associations has revealed that many of these men who supported Whitman in Britain and were friends of Lewes and Eliot seem to have formed the kind of subcultural affiliation envisioned by Eve Kosofsky Sedgwick, in which Leaves of Grass and photos of the poet functioned as an implicit conduit between members ("Toward the Twentieth Century" 205). Kathleen McCormack in George Eliot in Society lists many of these same men as visitors to Eliot's and Lewes's famous Sundays at the Priory during the 1860s and 1870s. See especially the subsection of Chapter Four titled "Gay and Lesbian Guests: 'Unknown Struggles of the Soul"' (92-106). According to McCormack, many of these men, along with a number of female friends of Eliot and Lewes, were members of the group she identifies as "gay and lesbian guests [that] made up a group of significant size" (80). Linda Dowling in Hellenism and Homosexuality in Victorian Oxford (Ithaca: Cornell University Press, 1994) has demonstrated that Greek culture was another "homosexual code" in the nineteenth century.

43 William Michael Rossetti, ed., Poems by Walt Whitman, (London: J. C. Hotten, 1868). Available on the Walt Whitman Archive (whitmanarchive.org). The censored poems were not necessarily the ones that could be deemed homoerotic. In fact, the poems depicting male affection were less likely to be censored by Rossetti, because they were thought generally to be less offensive than the frankly sexual male-female poems.

44 Just as Lewes's and Eliot's roles in Whitman's British reception have not been noticed by Whitman scholars, Conway's even more crucial function has been surprisingly underrepresented in Whitman scholarship, although Jerome Loving in Walt Whitman: The Song of Himself (Berkeley: University of California Press, 1999) does recognize Conway as one of Whitman's disciples. Without Conway's untiring mediation on behalf of Whitman, the British edition probably would not have come about. 
45 See Laurel Brake, Marysa Demoor, et al., "Rossetti, William Michael" in Dictionary of Nineteenth-Century fournalism in Great Britain and Ireland (London: British Library and University of Chicago Press, 2009).

46 See Whitman's 1889 remarks on Rossetti's “expurgation” and on Emerson's similar attempts to censor Whitman's poetry in Traubel's With Walt Whitman in Camden (WWC), 4:29-30, in the searchable complete edition available on the Walt Whitman Archive.

47 It was Conway who recruited publisher John Camden Hotten and the Whitman admirer William Michael Rossetti to edit a British edition of Whitman's poems, as Rossetti explains in his article "Walt Whitman's Poems" (London Chronicle [July 6, 1867], 352-354). For the reputation of Hotten, the Conway-Hotten-Rossetti relationship, and the publication history of the British edition of Whitman's poems, see Morton D. Paley's "John Camden Hotten and the First British Editions of Walt Whitman-'A Nice Milky Cocoa-Nut,"” Publishing History 6 (1980), 5-35.

48 See Dowden's essay on Whitman, "The Poetry of Democracy: Walt Whitman," Westminster Review 96 (July 1871), 33-68. Available on the Walt Whitman Archive (whitmanarchive.org).

49 Harold Blodgett, "Whitman and Dowden," American Literature 1 (May 1929), 171-182.

50 Dowden's “George Eliot” was published in the Contemporary Review 20 (August 1872), 403.

51 Anne Gilchrist's “An Englishwoman's Estimate of Walt Whitman” was published in the [Boston] Radical 7 (May 1870), 345-359. Her letters to and from Whitman are available at the Walt Whitman Archive (whitmanarchive.org).

52 Mathilde Blind discusses the friendship between George Eliot and Anne Gilchrist in George Eliot: A Biography (Boston: Roberts Brothers, 1883); hereafter, A Biography.

53 Elizabeth Porter Gould speculates that Anne Gilchrist probably introduced the works of Whitman to Eliot in Anne Gilchrist and Walt Whitman (1900), 34.

54 Kathleen McCormack recounts the purposes for which the Sunday Afternoons were orchestrated: "for the substantial gay and lesbian contingent, for the literary self-promotion George Eliot-and even more actively, Lewes-engaged in Sunday after Sunday; for the usefulness of the gatherings in furthering Lewes's scientific/ psychological interests; for the liveliness provided by the circulation of Lewes himself; for the occasional musical recital; or for the amount of publishing business conducted among the guests, the majority of whom-as editors, authors, reviewers, and fiction writers-had some connection with one or more Victorian periodicals" (George Eliot in Society 3).

55 George Eliot: Interviews and Recollection, ed. K. K. Collins (New York: St. Martin's Press, 2010), 91-92.

56 As an aside, it is interesting to note that George Eliot must have obtained Rossetti's 1868 British edition of Leaves of Grass because the lines she quotes were not included in the 1855 edition that she reviewed.

57 [Anonymous], "Walt Whitman," The Saturday Review (March 18, 1876), 360-361. Available on the Walt Whitman Archive (whitmanarchive.org). This review is accompanied by the following note by Archive staff, which provides some details 
regarding the ongoing controversy to which the review's author is responding: "Walt Whitman's Actual American Position' was an unsigned article published in the West fersey Press on January 26, 1876, lamenting the poet's poverty and his neglect by the United States. This article was written by Whitman himself, in a successful effort to incite international controversy over the value of his work. Excerpts from the article appeared in the London Athenaeum (March 11, 1876), followed by Robert Buchanan's and William Michael Rossetti's letters to the London Daily Nerws, attempting to rally assistance through a sale of subscriptions to Whitman's Leaves of Grass (1876)."

58 Nancy Henry encourages a practical interpretation. She observes that "Eliot's puritanical belief in renunciation of wealth never left her" whereas "Lewes was not burdened with this Calvinist impulse to scourge and renounce. In this sense he was an influence on her to accept a large offer of money, as he would also be in urging her to accept pleasures that her own earnings afforded, such as first-class travel, furniture, jewelry, and trips to fashionable spas. His guiltless negotiation of business deals for her writing released her from the painful conflicts she suffered over being rich, even though that guilt is reflected in her fiction" (The Life of George Eliot 135).

59 Queer readings of Eliot's fiction include Henry's impeccably researched "The Romola Code," which finds "Sex between males is everywhere in Romola" (327). Gouws's "Enthusiastic Bachelors" decodes homoerotic desire in Seth Bede and Dino de Bardi; Laura Callanan's “The Seduction of Daniel Deronda" (Women's Writing 3 [1996], 177-188) explores Daniel Deronda's and Mordecai's relationship. Other critical essays on same-sex desire in Eliot's texts include Monika Müller, "Nineteenth-Century Narraceons [sic]: Race, Gender, and (National) Identity in Harriet Beecher Stowe's Uncle Tom's Cabin and Dred and George Eliot's Daniel Deronda," Gender Forum 3 (2002); Joanne Long Demaria, "The Wondrous Marriages or Daniel Deronda: Gender, Work, and Love," Studies in the Novel 22 (1990), 403-417; and Jacob Press, "Same Sex Unions in Modern Europe: Daniel Deronda, Altneuland, and the Homoerotics of Jewish Nationalism," in Novel Gazing: Queer Readings in Fiction, ed. Eve Kosofsky Sedgwick (Durham: Duke University Press, 1997), 299-329. 